\title{
The Rice Straw Tying Device Parameters Using UG Software to Establish Three-Dimensional Model of Rice Harvest Tying Device Baling Machine
}

\author{
LIU Ying-nan ${ }^{1}$, YI Shu-juan ${ }^{2 *}$ and Sun Dian-qi ${ }^{3}$ \\ ${ }^{1}$ College of Electrical and Information, Heilongjiang Bayi Agricultural University, \\ Daqing 163319, China \\ ${ }^{2,3}$ College of Engineering, Heilongjiang Bayi Agricultural University, Daqing 163319, \\ China \\ 1dqpilyn@126.com, 2yishujuan_2005@126.com,3395831174@qq.com
}

\begin{abstract}
With the improvement of the utilization rate of straws, the recovery question of rice straw has been focused. In the past, the recovery of rice straw needs a lot of manpower. also need to be equipped with a vehicle, most of bundling machine were traction type bundling machine in domestic, secretary was inefficient, this greatly increases the cost of recycling, and the recovery of straw caused two compactions of soil, so that farmers will burn a lot of straw, cause pollution of the environment. Therefore, this study is based on the whole feeding rice combine harvester. added the straw bale device, One-time finished the rice harvesting, threshing cleaning and warehousing and Rice straw compression, bale and other processes. Improve the recovery efficiency of rice straw, reduce the cost of straw recovery, reduced the number of mechanicals going in the fields. In this paper using UG software for the rice harvest tying device baling machine $3 d$ drawing, and carries on the kinematics simulation, the simulation for bundling device compression mechanism motion state laws.
\end{abstract}

Key words: Rice harvesting bundling machine, Bundling apparatus, Virtual simulation

\section{Introduction}

For stem tying device research started late in our country, more developed countries are relatively backward technology, but also has its relatively perfect place, in the technical and theoretical study on the research of the parts have some, formed a series of models to adapt to the situation of our country, and each region according to climate condition has developed around the different types of straw baling machine. In technology, aiming at different types of rice straw baling machine deficiency, is improved and explored. For the normal operation of baling machine various agencies, lose the design of the grass machine, compression device stability, durability, blockage of knot and threshing effect, the parts the transmission way of research and improvement. In theory, our country tends to use UG, Pro/E and ADAMS software for every parts and components in the rice straw baler 3-d modeling, assembly and kinematics and dynamics simulation, and analysis the data of the whole machine for structure improvement and optimization [1].

Article history:

Received (January 4, 2020), Review Result (February 6, 2020), Accepted (March 11, 2020) 
Therefore, this research is widely used at present, on the basis of full feeding rice combine harvester, increase straw tying device, a one-time rice harvesting, threshing, cleaning, a levite, and the compression of rice straw and baling, improve the efficiency of the recovering of rice straw, decrease The Times of the machinery into laid the groundwork for the rice straw recycling better. For mounted on a combine harvester of rice straw tying device of virtual prototype design, simulation and experimental study on the device. By tying device best banding effect, flow smoothly for the subsequent storage transportation, has important significance for the development of environmental protection as well as a sideline.

\section{Combine harvester and tying device assembly design}

\subsection{General structure and working principle}

Rice harvest baling machine structure as shown in [Figure1], as shown in [Figure 2], the combine harvester and tying device assembly together, tying device installed in the side of combine harvester, according to the national standard GB/T25423-2010, knot tying device is mainly composed of compressed institutions, organizations, bale density regulating mechanism, bale length control mechanism and the composition of the body. Tying device of the input power is $8-10 \mathrm{kw}$, its appearance size is $2800 \mathrm{~mm} * 850 \mathrm{~mm} * 850 \mathrm{~mm}$, tying device weighs $650 \mathrm{~kg}$, and the combine of form a complete set of power should be 81-110 kw. Selection fukuda thunder god vogosmart GE50, combine the power of $81 \mathrm{kw}$, installed on the side of the output straw tying device [2].

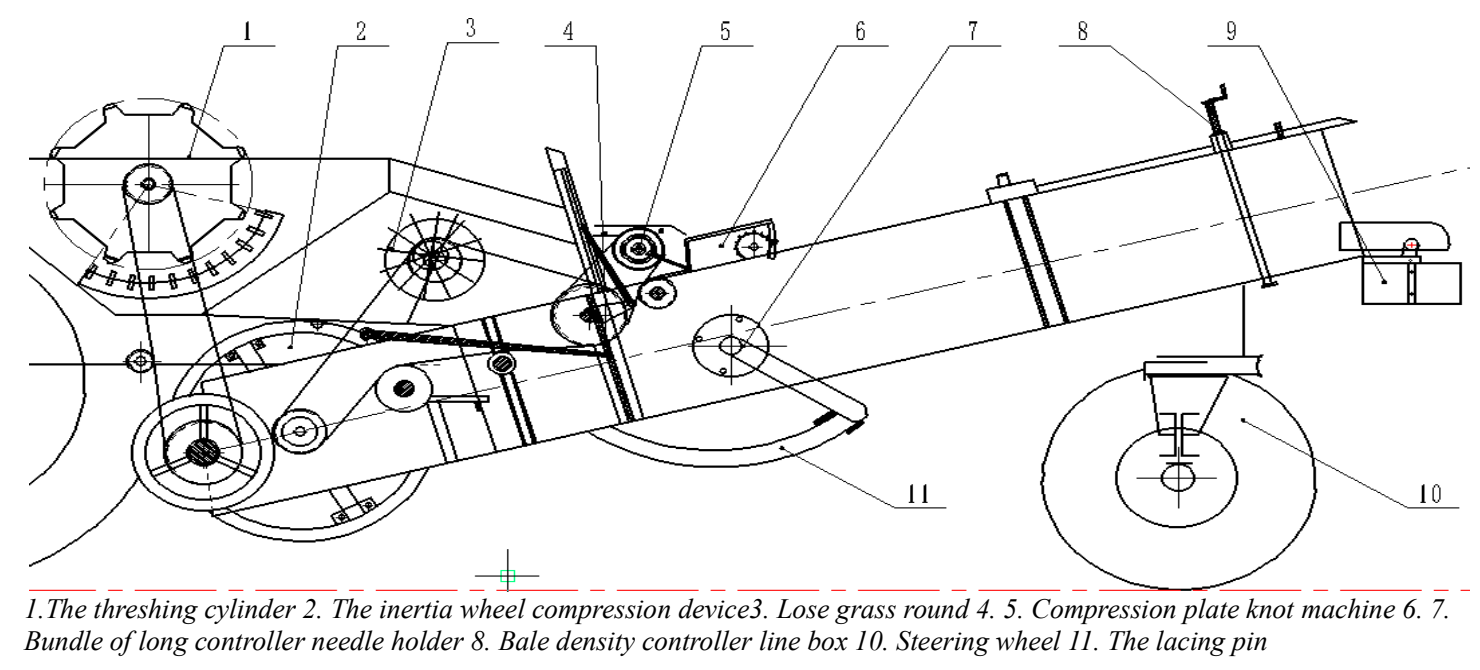

Figure 1. Schematic structure of rice harvest tying unity machine' tying device

Device and its working principle is: after the power is derived from the combine harvester threshing cylinder, both through the chain wheel is linked together, when by the cylinder threshing rice, rice straw by feeding fork feeding into tying device baling operations, into after tying device haulm by losing grass round in transmission, grilled lose grass wheel is telescopic tooth structure, as shown in [Figure 3], for no teeth and toothed phases, telescopic steak when turning to the left tooth will extend the shell, turn to the right when the tooth is retracted into the shell. 


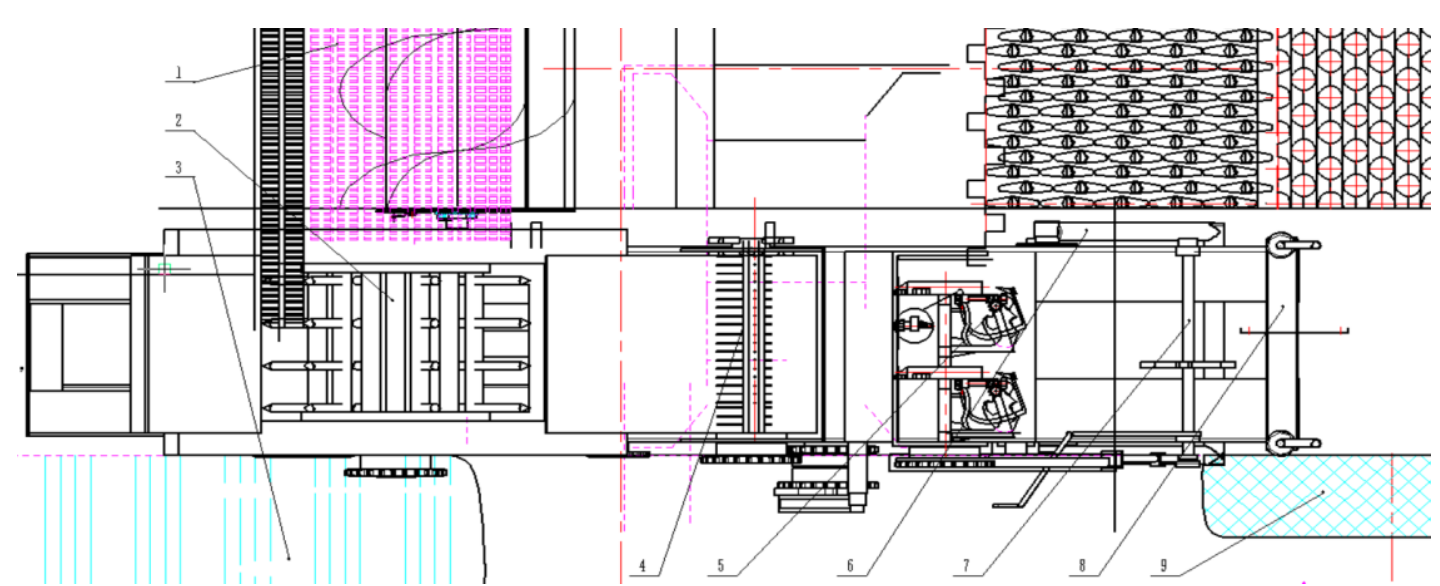

1.threshing cylinder 2. threshing roller feeding wheel 3.combine dynamic round 4. Send grass wheel5. Knot machine 6. Lacing beard needle frame 7. Bale length controller 8. Bale density controller 9. steering wheel

Figure 2. Overhead view of rice harvest tying unity machine' tying device

When the compactor over losing grass when the wheel is compressed lose grass round entered the stage of anodontia, not for straw feed, when compactor during a compression stroke, lose the grass into the toothed wheel stage, for delivery of straw. When straw bundle after reaching a certain length, bundle of long controller adjust knot clutch closed, needle rack and lacing the knot to Pierce the bale, wearing rope after reach knot machine needle knot to knot, knot homework finished, needle and the aircraft back to its original position, knot clutch just turn a week, in under the action of bale length control mechanism, knot clutch disconnect, tying device began to accumulate a bale [3].

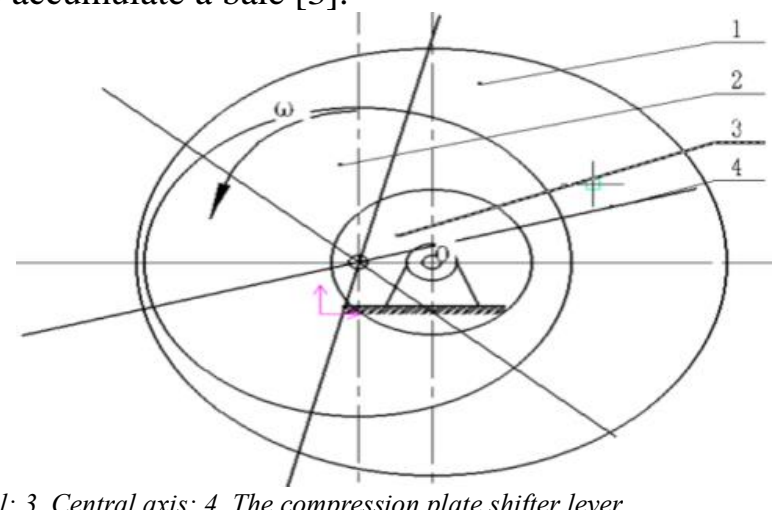

1.The shell; 2. Dial rod shell; 3. Central axis; 4. The compression plate shifter lever

Figure 3. Compression mechanism of rice harvest tying unity machine' tying device

Rice harvest tying device baling machine banding effect is through the threshing cylinder rotation speed, and harvest of baling machine speed, the moisture content of rice straw, baling machine bale length controller, bale density regulator to adjust, such as tying device by changing the parameters can influence the operation effectiveness and efficiency. Mutual cooperation of every parts and components in the collaboration, tying device can achieve the best baling requirements, to achieve the effect of straw bale neat, moderate density, complete rice straw recycling, bring greater benefits to peasants. According to the national standard GB/T25423-2010, with reference to agricultural machinery design manual, tying device design, determine the main rice harvest tying device baling machine design parameters as shown in [Table 1]: 
The Rice Straw Tying Device Parameters Using UG Software to Establish Three-Dimensional Model of Rice Harvest Tying Device Baling Machine

Table1. Main design parameters of the whole machine of rice harvesting and bundling machine

\begin{tabular}{|c|c|}
\hline The project name & parameter \\
\hline Threshing cylinder rotation speed $/ \mathrm{r} \cdot \mathrm{min}-1$ & $800-1200$ \\
\hline Feeding amount $(\mathrm{kg} / \mathrm{s})$ & $2-6$ \\
\hline The moisture content $\%$ & $20-40$ \\
\hline The input powerkw & $8-10$ \\
\hline Overall dimensions (length x width $\mathrm{x}$ height $) / \mathrm{mm}$ & $876 \times 445 \times 326$ \\
\hline The compression chamber (width $\mathrm{x}$ height $)(\mathrm{mm})$ & $310 \times 460$ \\
\hline Working hours and productivity $/ \mathrm{hm} 2 \cdot \mathrm{h}-1$ & $20-40$ \\
\hline Feeding mechanism type & Fork type feeding mechanism \\
\hline The length of the bale $(\mathrm{mm})$ & $300-1200$ \\
\hline
\end{tabular}

\section{Virtual prototype simulation and analysis}

\subsection{Build motion model}

Tying device in order to visually display the rice harvest baling machine all parts, motion knot on compression institutions, institutions and bale length control institutions, when conducting independent drive. Use UG8.0 motion simulation module of kinematic pair of the drive function to various agencies to add power, the initial displacement is zero; Initial speed from zero to a constant speed, determination of institutions at constant speed from zero to the movement of parts.

\subsection{Movement simulation}

Virtual rice straw from a threshing roller by losing grass device to the compression chamber, by compression, compression device again a little bit of education tying device, be consistent with baling rice straw in the real situation, there are rice straw as tooth disk drive bale length control mechanism motion, the tying device to work, motion simulation, first converts assembly module of UG to motion simulation module. Connecting rod set of $3 \mathrm{~d}$ entity model, the establishment of kinematic pair and external load add pre-processing work and so on, complete the construction of motion model. First movement simulation of compression mechanism, power comes from threshing cylinder compression mechanism, the reducer output end of the set has a power driven sprocket movement, the whole device movement, movement analysis of the motion simulation and now the toolbar, to create the motion model of motion simulation, select "new solutions", set up the regular driver solution types, analysis of type "kinematic/dynamic," time is $60 \mathrm{~s}$, count to 360, click ok to complete the motion simulation of rice harvest tying device baling machine [4].

\subsection{Movement simulation results analysis}

"In the" sports navigator "motion1", a new compression plate on a bit as a link named "J003", select on compression institutions compression plate "J003" as a sign of corresponding points, right click on the "new decoding scheme choice, pop-up" decoding scheme "dialog box, set the corresponding parameters, click the" ok "button. Click the play 
button to play the corresponding animation, animation can intuitive view the motion state institutions, and output compression plate stress, velocity and acceleration curve.

\subsection{Compression process stability analysis}

[Figures 4] and [Figures 5] show the displacement and velocity curves of the compression plate of the compression device and [Figure 6] shows the acceleration of the compression plate of the compression device. It shows the displacement, velocity and acceleration of the compression plate when the speed of the compression plate increases from zero to a constant speed under the condition of the constant rotation of the sprocket.

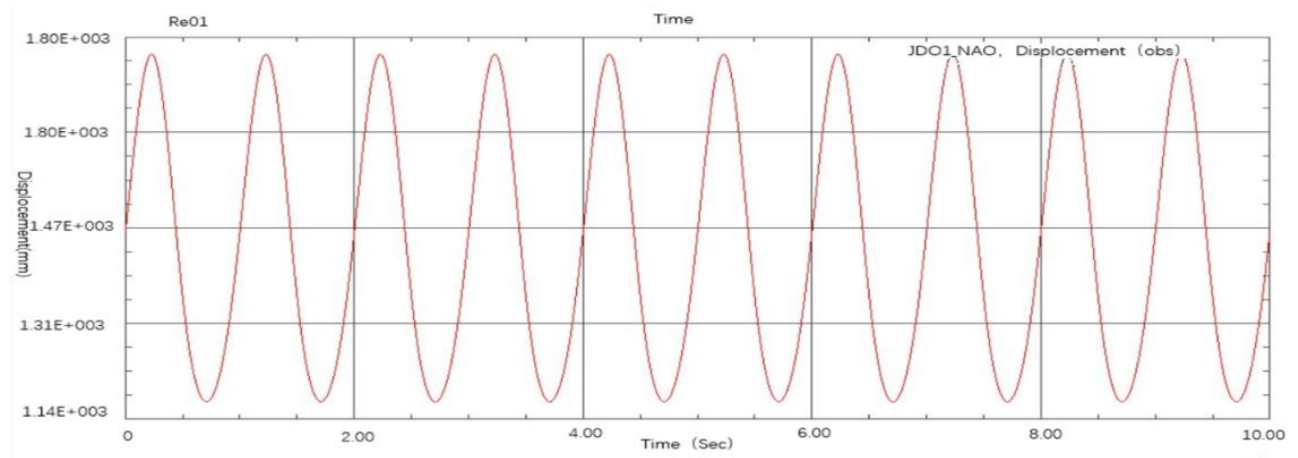

Figure 4. The displacement curve of compression plate

From [Figure 4] can be analyzed, the movement displacement compressor compactor from scratch to increase to a maximum positive direction, and then towards the direction, the entire journey through the path of $660 \mathrm{~mm}$, this is the same as the diameter of the flywheel, explain the movement accurately. Compression device movement displacement curves present a sine rule, sine curve shows its motion stability, no bumps, sharp point. Line take exercise in the period of the shortest line, rotary reciprocating motion, and turning trajectory, compression plate displacement of first cycle of reciprocating movement back and forth.

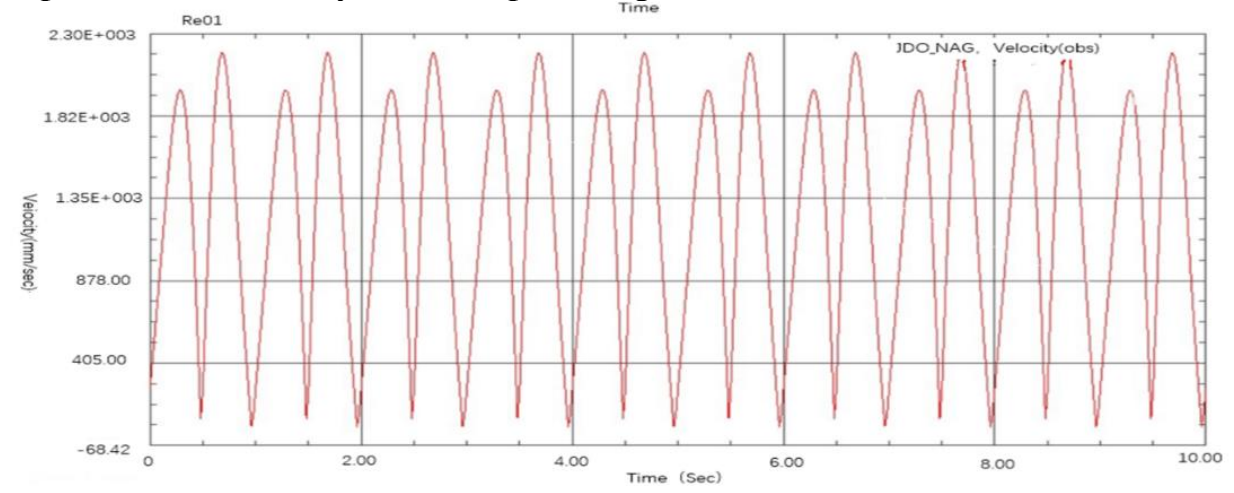

Figure 5. Absolute speed curve of compression plate of compression device

As shown in [Figure 5], 0 point to a maximum velocity moment, this paragraph of time is compressed device compactor compress the rice straw into the compression chamber began, all the way to the compression chamber fed near the entrance, the running speed of the compressor compactor is always on the rise, until the compression chamber feed near the entrance to the maximum of compression device compactor run once the bottom marked 
changes in the velocity of the point, the maximum moment from speed to speed to zero point, compactor is to compress the end compression, the horizontal direction of marked points points rate has been decreasing, and compression end point, rate of 0 , compress the device compactor will forage fast extrusion; Compactor from compression device speed fast, slow running, this is advantageous to the compression device compactor fixed for compaction of pasture; Compactor from compression device to run to the compression chamber the flute; From the compression device compactor began returning to run, faster; To towards the other end of compactor rate began to fall, the compression apparatus compactor operation right side began to run down, feed into the house, run to the right side, the speed of 0 , the speed is slow, this time compression device compactor gently away from the compression chamber.

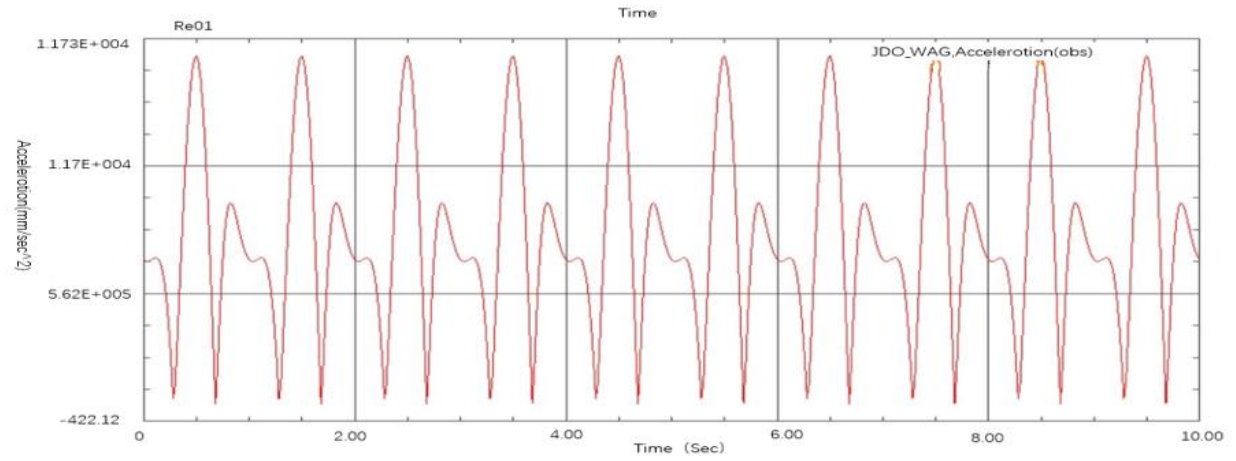

Figure 6. Absolute acceleration curve of compression plate of compression device

As shown in [Figure 6], the acceleration of a compression device to increase, in just the compression stress increases gradually, when the rice straw machine is unstable, after reaching the maximum, the acceleration is no longer increasing, the force required to tying device after the range of 0 to the maximum, when the compression device movement after a period of time, the acceleration is reduced, but also in stress, the acceleration is zero, the speed stable value, compress the devices are working at a certain speed. Compression device connected to the follow-up of a series of device, the movement rule can effectively reflect the motion state of the entire device, with its as the analysis of the device has certain powers of persuasion.

\section{Experimental study}

\subsection{Test index}

(1) The rate of bundles

Direct influence on the reliability of the tying device bundles rate, high rate of bundles, that tying device can run normally, bundles rate is an important indicator of baling device could be used. Before the bales rate for bale number and the ratio of the total number of bale [5].

$$
X=\frac{m_{a}}{m_{b}} \times 100 \%
$$

Type: $X$ as the rate of bales, $\% ; m_{a}$ For before the bale number; $m_{b}$ As the total number of bales.

(2) Rule bound rate 
Rule bound rate shows that bundles of rule, rule bound rate is high, the description of bale shape rules, easy to transport, stacking and another follow-up work. By literature, the size of the straw bale length direction of the maximum and the minimum $10 \%$ of the average no greater than the difference between the long side for rules bundle, whereas for irregular sheaf, rules bound rate is equal to bale number and the ratio of the total straw bale rope [6].

$$
C=\frac{m_{1}}{m_{2}} \times 100 \%
$$

Type: $C$ rules for bound rate, $\% ; m_{1}$ Rules for bale number; $m_{2}$ As the total number of bale.

(3) Bale density

Bale density is determined by the quality and size of straw bale, with the method of mass divided by volume density of straw bales.

$$
\rho=\frac{m}{v}
$$

Type: $\rho$ for bale density, $\mathrm{kg} / \mathrm{m}^{3} ; m$ For the quality of bale, $\mathrm{kg} ; v$ As the bale size, $\mathrm{m}^{3}$.

(4) Pure working hour rate

Pure working hour rate calculated by type (4.4):

$$
E_{\mathrm{cx}}=\frac{M_{d}\left(I_{d}-I_{S}\right)}{T_{c}}
$$

Type: $E_{\mathrm{cx}}$ - pure work hour productivity, $\mathrm{kg} / \mathrm{h} . I_{d}$-pure working time accumulative total number of baling, bundle [7]; $I_{d^{-}}$pure accumulative bundle off work time, bundle; $M_{d^{-}}$-bale average equivalent quality, $\mathrm{kg} / \mathrm{bundle}$. $T_{c}$-pure working time, $\mathrm{h}$.

\subsection{The field tests}

\subsubsection{Orthogonal experiment design}

On the basis of single factor experiment, and through the implement of the feeding amount, bale length and height of three factors of the export of single factor experiment, obtained the data and the corresponding parameter values. Including feeding amount in $2 \mathrm{~kg} / \mathrm{s}, 2.5 \mathrm{~kg} / \mathrm{s}, 3$ $\mathrm{kg} / \mathrm{s}$, bale length is $500.0 \mathrm{~mm}, 600.0 \mathrm{~mm}$ and $700.0 \mathrm{~mm}$, height is $240.0 \mathrm{~mm}, 240.0 \mathrm{~mm}$ and $260.0 \mathrm{~mm}$, the effect of rice straw bale is better, bale be born is not easy to break, drying and the subsequent loading work is more favorable. Therefore, the feed rate, bale length, height of export of three factors three levels orthogonal experiment was carried out, get a optimal parameter values. The orthogonal experiment scheme as shown in [Table 2-3].

Table 2. The choose of factors for the experiment of orthogonal test

\begin{tabular}{|c|c|c|c|c|}
\hline factors & $\begin{array}{c}\text { Feeding amount } \\
\left(\mathrm{kg} \cdot \mathrm{s}^{-1}\right)\end{array}$ & Null columns & $\begin{array}{c}\text { The length of the bale } \\
(\mathrm{mm})\end{array}$ & Export highly $(\mathrm{mm})$ \\
\hline level & $\mathrm{A}$ & $\mathrm{B}$ & $\mathrm{C}$ & $\mathrm{D}$ \\
\hline 1 & 2.0 & 1 & 500 & 240 \\
\hline 2 & 2.5 & 2 & 600 & 250 \\
\hline 3 & 3.0 & 3 & 700 & 260 \\
\hline
\end{tabular}

Table 3. The test program of orthogonal test

\begin{tabular}{|c|c|c|c|c|c|}
\hline level & A & B & C & D & Test plan \\
\hline
\end{tabular}


The Rice Straw Tying Device Parameters Using UG Software to Establish Three-Dimensional Model of Rice Harvest Tying Device Baling Machine

\begin{tabular}{|c|c|c|c|c|c|c|c|}
\hline & & & & & Bales rate \% & $\begin{array}{c}\text { Rules of the } \\
\text { bundle of rate } \%\end{array}$ & Bale densityKg/m \\
\hline 1 & 1 & 1 & 1 & 1 & 100 & 83 & 89.38 \\
\hline 2 & 1 & 2 & 2 & 2 & 90 & 90 & 85.56 \\
\hline 3 & 1 & 3 & 3 & 3 & 100 & 83 & 81.05 \\
\hline 4 & 2 & 1 & 2 & 3 & 100 & 85 & 90.29 \\
\hline 5 & 2 & 2 & 3 & 1 & 87 & 83 & 95.26 \\
\hline 6 & 2 & 3 & 1 & 2 & 100 & 80 & 93.68 \\
\hline 7 & 3 & 1 & 3 & 2 & 81 & 96 & 98.46 \\
\hline 8 & 3 & 2 & 1 & 3 & 100 & 100 & 94.93 \\
\hline 9 & 3 & 3 & 2 & 1 & 89 & 87 & 104.14 \\
\hline
\end{tabular}

\subsubsection{The orthogonal experiment result analysis}

Table 4. The orthogonal test results and analysis

\begin{tabular}{|c|c|c|c|c|c|c|c|c|c|}
\hline \multirow[t]{2}{*}{$\mathrm{K}$ value } & \multicolumn{3}{|c|}{ Bales rate $\%$} & \multicolumn{3}{|c|}{ Rules of the bundle of rate $\%$} & \multicolumn{3}{|c|}{ Bale densityKg $\mathrm{Kg} / \mathrm{m}^{3}$} \\
\hline & A & B & $\mathrm{C}$ & A & B & $\mathrm{C}$ & A & B & $\mathrm{C}$ \\
\hline$K_{1}$ & 290.00 & 281.00 & 300.00 & 256.00 & 264.00 & 263.00 & 162.88 & 208.56 & 238.76 \\
\hline$K_{2}$ & 287.00 & 290.00 & 279.00 & 248.00 & 273.00 & 262.00 & 238.07 & 241.82 & 228.17 \\
\hline$K_{3}$ & 287.00 & 289.00 & 268.00 & 284.00 & 253.00 & 262.00 & 300.54 & 251.14 & 234.56 \\
\hline$k_{l}$ & 96.67 & 93.67 & 100.00 & 85.33 & 88.00 & 87.67 & 54.29 & 69.52 & 79.59 \\
\hline$k_{2}$ & 95.67 & 96.67 & 93.00 & 82.67 & 91.00 & 87.33 & 79.36 & 80.61 & 76.05 \\
\hline$k_{3}$ & 90.00 & 96.33 & 89.33 & 94.67 & 84.33 & 87.33 & 100.18 & 83.71 & 78.19 \\
\hline Range $\mathrm{R}$ & 6.67 & 3.00 & 10.67 & 12 & 6.67 & 0.34 & 45.89 & 14.19 & 3.54 \\
\hline $\begin{array}{l}\text { Analyze the } \\
\text { optimal level }\end{array}$ & $\mathrm{A}_{3}$ & $\mathrm{~B}_{3}$ & $\mathrm{C}_{3}$ & $\mathrm{~A}_{2}$ & $\mathrm{~B}_{3}$ & $\mathrm{C}_{3}$ & $\mathrm{~A}_{1}$ & $\mathrm{~B}_{1}$ & $\mathrm{C}_{2}$ \\
\hline $\begin{array}{c}\text { Primary and } \\
\text { secondary } \\
\text { factors } \\
\end{array}$ & & ACB & & & $\mathrm{CBA}$ & & & $\mathrm{CAB}$ & \\
\hline
\end{tabular}

Obtained from [Table 4]: the primary and secondary factors influencing the three indicators and the optimal level for: $\mathrm{A} 1 \mathrm{C} 1 \mathrm{~B} 2$ bundles rate; Rules $\mathrm{C} 1 \mathrm{~B} 2 \mathrm{~A} 3$ bound rate; C1A3B3 bale density. Through comprehensive analysis, select test factors of the optimal level combination for A1B3C3; It bound rate of $96.67 \%$; Rules of the bundle at a rate of $87.67 \%$; Bale density of $79.59 \mathrm{~kg} / \mathrm{m}^{3}$.

(1) The influence of three factors on the rate of bundles 


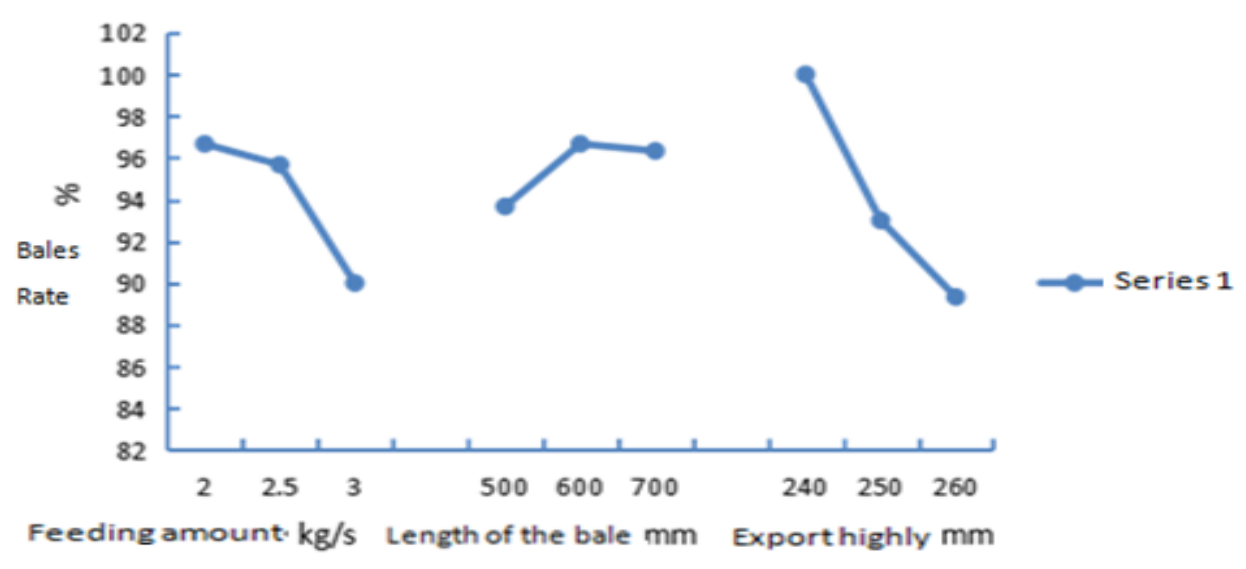

Figure 7. The results of factor test of Height of exit

Table 5. The variance analysis results table of shattering rate

\begin{tabular}{|c|c|c|c|c|c|}
\hline The source & $\begin{array}{c}\text { Type III sum of } \\
\text { squares }\end{array}$ & df & mean square & F & Sig. \\
\hline $\begin{array}{c}\text { Correction } \\
\text { model }\end{array}$ & $414.000 \mathrm{a}$ & 6 & 69.000 & 5.545 & .161 \\
\hline $\begin{array}{c}\text { Correction } \\
\text { model }\end{array}$ & 79712.111 & 1 & 79712.111 & 6405.438 & .000 \\
\hline $\begin{array}{c}\text { Feeding amount } \\
\text { The length of } \\
\text { the bale }\end{array}$ & 77.556 & 2 & 38.778 & 3.116 & .243 \\
\hline $\begin{array}{c}\text { Export highly } \\
\text { error }\end{array}$ & 24.889 & 2 & 80.111 & 7.080 & .124 \\
\hline total & 80151.000 & 9 & 12.444 & 6.437 & .134 \\
\hline $\begin{array}{c}\text { Correction of a } \\
\text { total }\end{array}$ & 438.889 & 8 & & & \\
\hline
\end{tabular}

The [Figure 7] shows that under the orthogonal experiment, the feed rate and export high effect on the rate of bundles is opposite bigger, but more than $85 \%$, bundles of rice rate is higher, shows that harvest baling machine effect is good. [Table 5-9] by the results of variance analysis, the influence on rice harvest baling machine bundles rate affect the order of the three factors of primary and secondary A feeding amount $(\mathrm{kg} / \mathrm{s})>\mathrm{D}$ export height $(\mathrm{mm})$ $(\mathrm{mm})>\mathrm{B}>\mathrm{C}$ bale length null columns, the optimal combination of the bales rate A3D1C2B1, the feed rate of $3.0 \mathrm{~kg} / \mathrm{s}$, bale length is $500 \mathrm{~mm}$, the export is A more optimal value when the height is $240 \mathrm{~mm}$.

(2) The influence of rate of three factors on the rules of bundle 


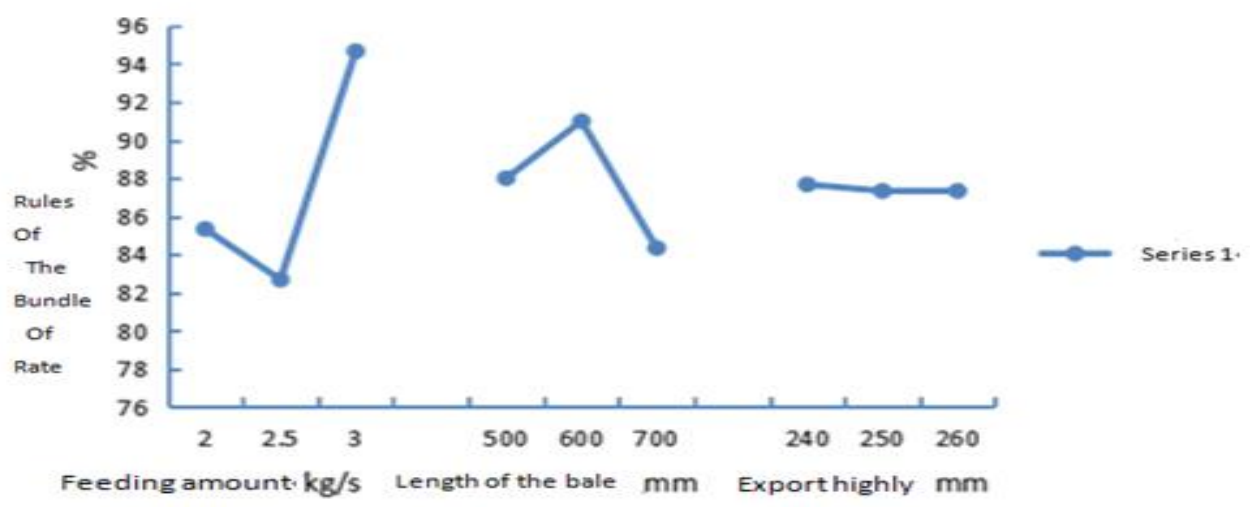

Figure 8. The results of factor test of Height of exit

Table 6. The variance analysis results table of falling rice rate

\begin{tabular}{|c|c|c|c|c|c|}
\hline The source & $\begin{array}{c}\text { Sum of } \\
\text { squares }\end{array}$ & $\mathrm{df}$ & mean square & $\mathrm{F}$ & Sig. \\
\hline $\begin{array}{c}\text { Correction } \\
\text { model }\end{array}$ & $268.667 \mathrm{a}$ & 6 & 44.778 & 1.000 & .578 \\
\hline $\begin{array}{c}\text { Correction } \\
\text { model }\end{array}$ & 68818.778 & 1 & 68818.778 & 1536.896 & .001 \\
\hline $\begin{array}{c}\text { Feeding } \\
\text { amount }\end{array}$ & 224.222 & 2 & 112.111 & 2.504 & .285 \\
\hline $\begin{array}{c}\text { The length of } \\
\text { the bale }\end{array}$ & 44.222 & 2 & 22.111 & .494 & .669 \\
\hline Export highly & .222 & 2 & .111 & .002 & .998 \\
\hline error & 89.556 & 2 & 44.778 & & \\
\hline total & 69177.000 & 9 & & & \\
\hline $\begin{array}{c}\text { Correction of } \\
\text { a total }\end{array}$ & 358.222 & 8 & & & \\
\hline
\end{tabular}

The [Figure 8] shows that under the condition of the orthogonal experiment, feeding amount, bale length of the rules bundle of rate is larger, the influence of the height of export less effect on the rate of rules trapped, table 6 by the results of variance analysis, the influence on rice harvest baling machine bundles rate affect the order of the three factors of primary and secondary A feeding amount $(\mathrm{m} / \mathrm{s})>\mathrm{D}$ export height $(\mathrm{mm})(\mathrm{mm})>\mathrm{B}>\mathrm{C}$ bale length null columns, the optimal combination of the bales rate A3D1C2B1, the feed rate of $3.0 \mathrm{~m} / \mathrm{s}$, bale length is $600 \mathrm{~mm}$, the export is A more optimal value when the height is $240 \mathrm{~mm}$.

(3) The influence of three factors on the bale density 


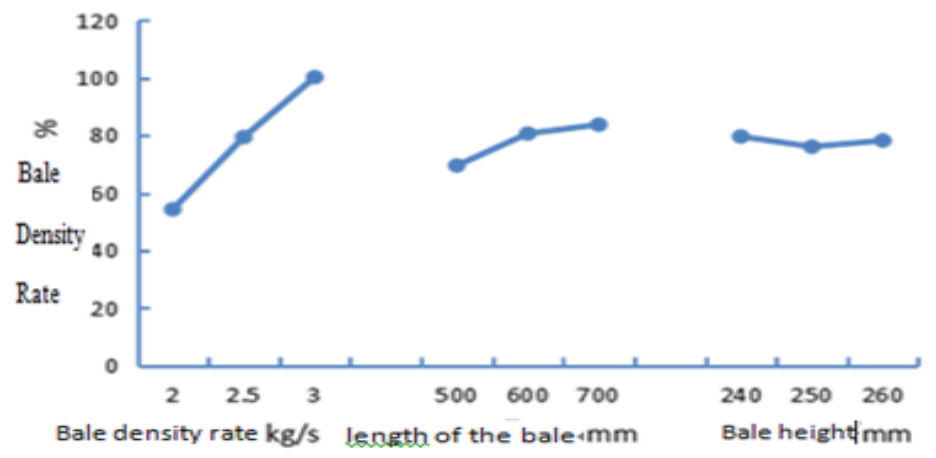

Figure 9. The results of factor test of Height of exit

Table 7. The variance analysis results table of uncut rate

\begin{tabular}{|c|c|c|c|c|c|}
\hline The source & $\begin{array}{c}\text { Type III sum of } \\
\text { squares }\end{array}$ & df & mean square & F & Sig. \\
\hline $\begin{array}{c}\text { Correction } \\
\text { model }\end{array}$ & $378.123 \mathrm{a}$ & 6 & 63.020 & 71.466 & .014 \\
\hline $\begin{array}{c}\text { Correction } \\
\text { model }\end{array}$ & 77051.212 & 1 & 77051.212 & 87377.449 & .000 \\
\hline $\begin{array}{c}\text { Feeding amount } \\
\begin{array}{c}\text { The length of } \\
\text { the bale }\end{array}\end{array}$ & 288.965 & 2 & 144.483 & 163.846 & .006 \\
\hline $\begin{array}{c}\text { Export highly } \\
\text { error }\end{array}$ & 84.532 & 2 & 2.313 & 2.623 & .276 \\
\hline total & 77431.098 & 9 & .882 & 47.931 & .020 \\
\hline $\begin{array}{c}\text { Correction of a } \\
\text { total }\end{array}$ & 379.886 & 8 & & & \\
\hline
\end{tabular}

The [Figure 9] shows that the orthogonal experiment, the feed rate and export level has obvious effects of straw bale density, the length of the bale factors have no obvious impact on bale density, [Table 7] by the results of variance analysis, the influence of rice harvest straw bale density baling machine order three factors of primary and secondary feed rate $(\mathrm{kg} / \mathrm{s})>\mathrm{C}$ exit height $(\mathrm{mm})(\mathrm{mm})>\mathrm{B}>\mathrm{D}$ bale length null columns, the optimal combination of the bale density rate $\mathrm{A} 2 \mathrm{C} 3 \mathrm{D} 2 \mathrm{~B} 1$, the feed rate of $2.5 \mathrm{~m} / \mathrm{s}$, bale length is $700 \mathrm{~mm}$, the export is a more optimal value when the height is $250 \mathrm{~mm}$.

Synthetically analysis of orthogonal test, the feed rate of $2.5 \mathrm{~m} / \mathrm{s}$, bale length is $700 \mathrm{~mm}$, the combination of export height is $240 \mathrm{~mm}$ for the optimal combination.

\subsection{Validation test}

Through the analysis of single factor and orthogonal experiment result shows that when the feed rate of $2.5 \mathrm{~kg} / \mathrm{s}$, bale length is $700 \mathrm{~mm}$, the height is $240 \mathrm{~mm}$ for the optimal value. As a result, the optimal value for the five times further validation of the test, to get the corresponding test data, as shown in the following [Table 8], because the validation test is essentially the same time to complete, so the moisture content of rice straw basic same, measured the moisture content of rice straw is $36 \%-40 \%$, and the single factor test and orthogonal test the moisture content of basic same, remove the influence of moisture content 
on test results, according to the test data is 5 bundles of data rate, rules, bundle of rate and bale density, and carry on comparative analysis to draw a line chart [8].

Table 8. The parameter of verification test

\begin{tabular}{|c|c|c|c|c|c|c|}
\hline $\begin{array}{c}\text { Group } \\
\text { number }\end{array}$ & $\begin{array}{c}\text { Feed } \\
\text { quantity } \\
\mathrm{kg} / \mathrm{s}\end{array}$ & $\begin{array}{c}\text { The length of } \\
\text { the bale } \mathrm{mm}\end{array}$ & $\begin{array}{c}\text { Export highly } \\
\mathrm{mm}\end{array}$ & Bales rate \% & $\begin{array}{c}\text { Rules of the } \\
\text { bundle of } \\
\text { rate } \%\end{array}$ & $\begin{array}{c}\text { Bale } \\
\text { densityKg/m }\end{array}$ \\
\hline 1 & 2.5 & 700 & 240 & 98 & 87 & 97.32 \\
\hline 2 & 2.5 & 700 & 240 & 96 & 89 & 101.1 \\
\hline 3 & 2.5 & 700 & 240 & 99 & 92 & 94.93 \\
\hline 4 & 2.5 & 700 & 240 & 97 & 90 & 97.88 \\
\hline 5 & 2.5 & 700 & 240 & 96 & 86 & 93.56 \\
\hline
\end{tabular}

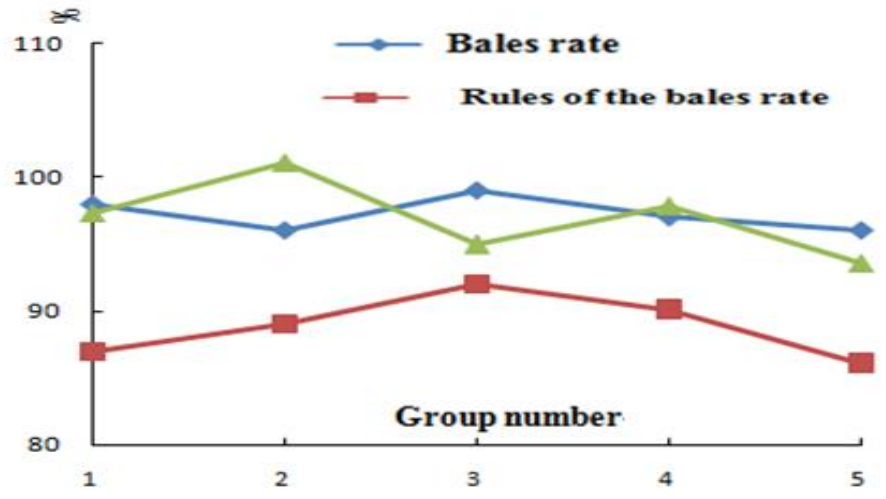

Figure 10. The line chart of verification test results

According to the experiment data, draw the line chart shown in [Figure 10], the figure shows that five bound rates close to its set of validation test, integrated test 5 groups, bundles at a rate of $97.2 \%$; Rule bound rate of $88.8 \%$, for bale density, 5 sets of test data is uniform, stable between 90 and 102. Comprehensive bale density of $96.9 \mathrm{~kg} / \mathrm{m}^{3}$, it follows that obtained by the orthogonal experiment, the better combination is more reasonable.

\section{Conclusions}

Development at home and abroad with the rice harvest baling machine, use and the development trend of rice tying device analysis as the foundation, through the theoretical analysis, the virtual prototype simulation analysis and experimental research method of combining the four SZD - 2 rice harvest tying device of baling machine motions were analyzed, and obtain the parameters of the rice and tying device after the optimal effect, get the following conclusion:

(1) Using UG software, the realization of the rice harvest baling machine $3 \mathrm{~d}$ modeling of parts of tying device, using the virtual prototype of rice harvest baling device compression mechanism movement simulation, the movement stability is analyzed. Simulated the rice harvest baling machine device in different speed, the stress environment of motion, the analysis results: compression compactor kinematic displacement is sine law of change, speed, acceleration and stress changing with time curve, its movement is more stable. 
(2) Being obtained by single factor experiment in feeding amount on bale density is larger, the influence of the increase due to the feed rate, increase in the number of rice JieGanLiang feed, straw bale density increased significantly; Bale length of the rules bundle of rate is larger, the influence of the bale length after arrived in 700, the bundle of straw bale rules rate is better than the bale under $600 \mathrm{~mm}$ length; Export height on bale density is larger, the influence of is inversely proportional to the bale density.

(3) By the orthogonal test analysis: experimental factors of the optimal level combination for bale length is $700.00 \mathrm{~mm}$, the feed rate is $2.5 \mathrm{~kg} / \mathrm{s}$, export height is $240.00 \mathrm{~mm}$; To get a better level of verification test, the resulting performance indicators for the bundles at a rate of $96.0 \%$; Rules of the bundle at a rate of $88.8 \%$; Bale density of $96.9 \mathrm{~kg} / \mathrm{m}^{3}$, the test results is better than the other combination, selecting reasonable a better level.

\section{References}

[1] LuJie, "Straw baling machine type D knot structure and parameter optimization research," The northeast agricultural university, (2014)

[2] Lee Ka Leung and Zhang Liang, "Trial report on yield of different forage maize varieties," Journal of Animal Husbandry and veterinary medicine, vol.35, no.1, pp.103-104, (2016)

[3] Xia Debin, "Nanshan district and alfalfa mechanical harvest after experimental study," Journal of modern animal husbandry, pp.30-43, (2014)

[4] Liu Xinzhu and Daniel, "The rice and wheat straw baler compression mechanism design and mechanical analysis," Journal of Jiamusi university, (2014)

[5] Tang Han, "Study on design and mechanism of finger-clip precision metering device for corn with corrugated curved surface," Harbin: Northeast Agricultural University, (2018)

[6] Ma Jun, "Introduction to comprehensive utilization of crop straw resources in Heilongjiang province present situation and the suggested," Journal of feed and the environment, (2014)

[7] Qu Hongchao, Bao Shuai, Yi Shujuan, etc., "Simulation and analysis of the bundling device of rice harvesting and bundling machine," Research on agricultural mechanization, no.11, pp.59-63, (2017)

[8] Li Fei jump and jian-fei wang, "China's grain crop straw burning carbon conversion and biochar carbon amount calculations,” Journal of Agricultural Engineering, pp.14:1-7, (2013) 
The Rice Straw Tying Device Parameters Using UG Software to Establish Three-Dimensional Model of Rice Harvest Tying Device Baling Machine

This page is empty by intention. 